\title{
Contact-style PGE-Cu-Ni mineralization: from genetic models to prospects
}

\author{
N.Yu. Groshev ${ }^{1}$, B.T. Karykowski ${ }^{2}$, W.D. Maier ${ }^{3}$, S.-J. Barnes ${ }^{4}$, P.V. Pripachkin ${ }^{1}$, \\ T.V. Rundkvist ${ }^{1}$, D.G. Stepenshchikov ${ }^{1}$, A.V. Chernyavsky ${ }^{1}$, A.A. Kompanchenko ${ }^{1}$ \\ and T.V. Kaulina ${ }^{1}$ \\ ${ }^{1}$ Geological Institute, Kola Science Centre, Russian Academy of Sciences, Russia \\ ${ }^{2}$ Volkswagen AG, Germany \\ ${ }^{3}$ Cardiff University, UK \\ ${ }^{4}$ Sciences de la Terre, Université du Québec à Chicoutimi, Canada \\ *Corresponding author e-mail: nikolaygroshev@gmail.com
}

\begin{abstract}
Summary It is proposed to distinguish two genetic types of primary magmatic contact-style PGE-CuNi mineralization using the example of the Monchegorsk Complex: 1) "gravitational" and 2) "intrusive". The presentation discusses features of the formation of these two types of the mineralization with an emphasis on their potential economic significance.
\end{abstract}

\section{Introduction and background to current research}

The main type of PGE mineralization in layered intrusions consists of laterally extensive reefs located within the cumulate pile of the intrusions. Deposits of the Merensky, UG-2 and J-M reefs are well known, being mined, and provide most platinum group metals to the world market. In recent years, the importance of another type of PGE-Cu-Ni mineralization located near the base of layered intrusions and regarded as contact-style has sharply increased. Firstly, this is due to the discovery of the deep levels of the Platreef in Bushveld, namely the Flatreef deposit. Secondly, if we look at the layered intrusions of Fennoscandia, then, in comparison with internal reefs, contact-style PGE mineralization have the greatest prospects due to the large volumes of discovered resources. At the moment, Suhanko (Finland) and Fedorova Tundra (Russia) are the two main projects in the region, the closest to a mining stage and both targeting contact-style PGE mineralization.

Prospecting and thematic works in recent years reveal a great potential for contact-style PGE-Cu-Ni mineralization near the base of the Paleoproterozoic Monchegorsk Complex, located approximately $120 \mathrm{~km}$ south of Murmansk on the Kola (Murmansk) Region of Russia. Exploration within selected areas of the complex, targeting the mineralized contact between the intrusion and the floor rocks, has shown 27.8 million tonnes (Mt) of category $\mathrm{C} 1+\mathrm{C} 2$ mineral reserves at $0.6 \mathrm{ppm}$ Pt and $1.1 \mathrm{ppm}$ Pd (Karykowski et al. 2018).

The Monchegorsk Complex comprises the largely ultramafic Monchepluton $\left(\sim 65 \mathrm{~km}^{2}\right)$ and the mafic Main Ridge $\left(\sim 485 \mathrm{~km}^{2}\right)$, resulting in a total areal extent of about $550 \mathrm{~km}^{2}$ (Fig. 1 inset). The two igneous bodies are separated by the NW-trending Monchetundra Fault (e.g., Sharkov 2006). The Monchepluton is crescent-shaped and consists of six hills which are arranged in two branches: the 7-km-long ultramafic NKT Massif (Mts. Nittis, Kumuzhya, Travyanaya) and a 9-km-long mafic-ultramafic branch, consisting of Mts. Sopcha, Nyud and Poaz. Additionally, a chromite-rich dunitic body, known as the "Dunite Block", occurs at the intersection of the two branches. The stratigraphy of the Monchepluton can be subdivided into five major zones. These are from the bottom to the top: (1) the Peridotite Zone with approximately $500 \mathrm{~m}$ in thickness, including the Dunite Block; (2) the Interlayered PeridotitePyroxenite Zone, reaching up to $300 \mathrm{~m}$ in thickness; (3) the Pyroxenite Zone with $>750 \mathrm{~m}$ in 
thickness; (4) the Noritic Zone in the upper portion of the intrusion with a thickness of at least $450 \mathrm{~m}$ and (5) the Gabbroic Zone with more than $700 \mathrm{~m}$ in thickness, comprising the Vuruchuaivench intrusion, which has been shown to represent the continuation of the underlying Noritic Zone (Rundkvist et al. 2016). The Main Ridge comprises the Volchetundra, Monchetundra and Chunatundra intrusions, which represent three tectonic blocks of an originally continuous intrusion with a thickness of more than $2500 \mathrm{~m}$. These intrusions are largely leucogabbronoritic to anorthositic in composition and relatively homogenous along strike (e.g., Sharkov and Chistyakov 2012). It is likely that the Main Ridge forms the upper part of the Monchepluton and therefore the continuation of the Gabbroic Zone.

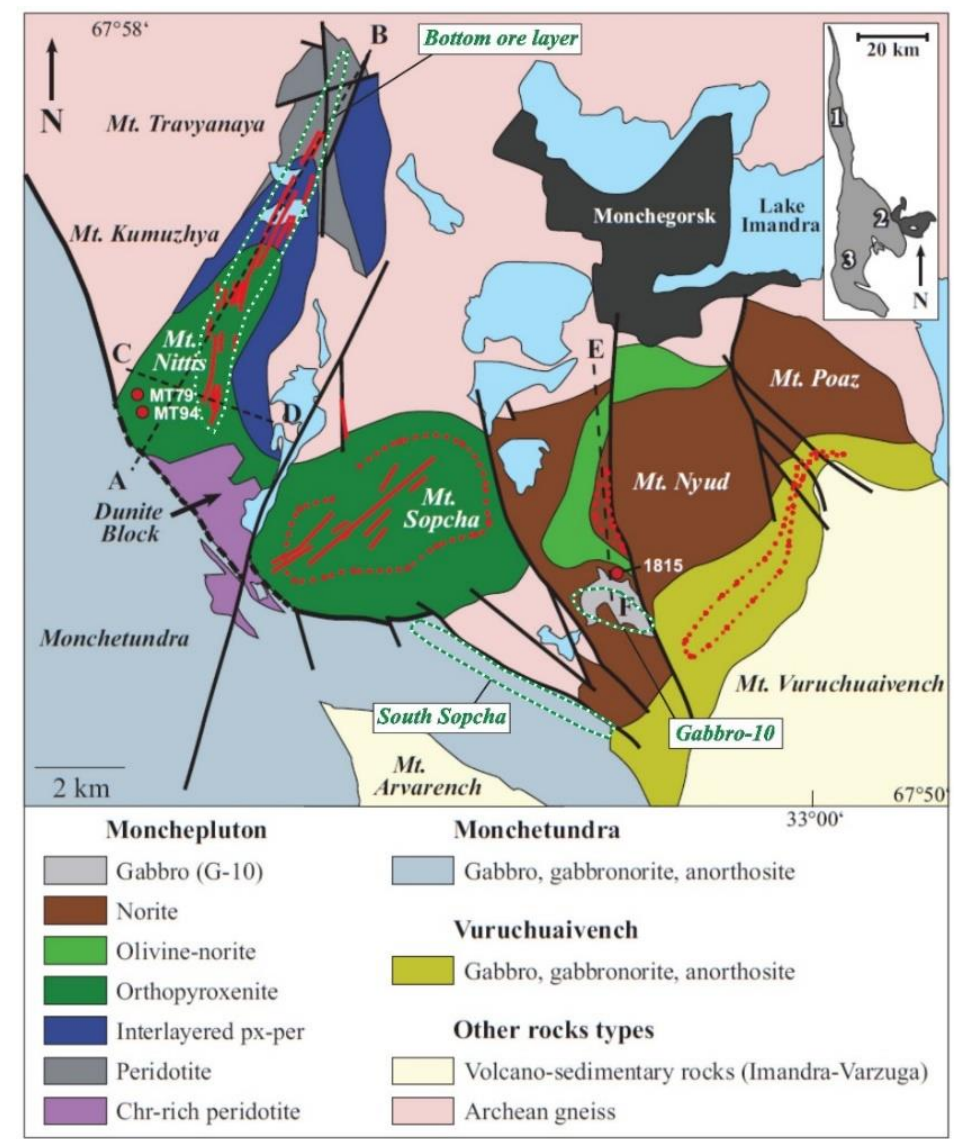

Figure 2. Simplified geologic map of the Monchegorsk Complex, modified after Karykowski et al. (2018). The location of diamond drill holes crossed "gravitational" PGE mineralization of contact-style are shown as red circles; "intruded" contact-style PGE mineralization is outlined by green dashed lines. Solid and dashed red lines indicate Ni-Cu-PGE mineralization as cross-cutting veins and internal horizons respectively. $1=$ Volchetundra, $2=$ Monchetundra, $3=$ Chunatundra.

According to a series of studies two genetic types of contact-style PGE-Cu-Ni mineralization can be distinguished in the Monchegorsk Complex (Pripachkin et al. 2016; Groshev et al. 2018; Karykowski et al. 2018): 1) "gravitational" and 2) "intrusive".

\section{Research questions at hand}

\subsection{Genetic model for the first type "gravitational" mineralization}

As intersected by drill hole MT79 at Nittis (Fig. 1), the bulk of the sulfide mineralization, covering some $30 \mathrm{~m}$ at the base of the intrusion, is hosted by the same rock type as the overlying 
unit represented by layered orthopyroxenite (Karykowski et al. 2018). The mineralized horizon at Nyud constitutes an approximately 20 -m-thick unit of sulfide-bearing melanorite overlain by barren melanorite without a significant change in texture. Drill core profiles show that significant sulfide accumulation (up to $5 \mathrm{wt} \% \mathrm{~S}$ ) is exclusively associated with the basal contact zone of each intrusion. These zones are characterized by elevated base metal concentrations, reaching up to $2 \mathrm{wt} \%$ each $\mathrm{Cu}$ and $\mathrm{Ni}$ and $0.15 \mathrm{wt} \% \mathrm{Co}$, whereas precious metal concentrations may reach about 3 ppm PGE. Moreover, basement rock types are mineralized in spatial proximity to the mafic-ultramafic rocks. Another remarkable zone of mineralization occurs some $100 \mathrm{~m}$ above the basal contact at Nittis. The mineralization is hosted in several thin chalcopyrite veinlets, crosscutting the orthopyroxenitic cumulate over a vertical thickness of about $3 \mathrm{~m}$, and reaches more than 30 ppm PGE ( $\mathrm{Cu}-\mathrm{Pd}$ mineralization).

This type of mineralization likely occurs in all peripheral marginal zones of the Monchepluton composed of the same rock type as in the main zones. Its location and features are consistent with the model of Karykowski et al. (2018) where the key process of the formation is the efficient sulfide collection in marginal zones of the intrusion, demanding a multi-stage emplacement of the mafic-ultramafic succession and allowing for significant partial melting of the basement. The interaction between magma and basement leads to the local addition of water and, potentially, carbon dioxide to the magma, resulting in partial melting of cumulus phases and a reduction in viscosity of the interstitial melt. This increases the porosity of the mush in the vicinity of the lower intrusion contact, promoting preferential sulfide liquid accumulation at the base, while the local decrease in magma viscosity facilitates gravitational settling of sulfide droplets. These factors lead to an efficient collection of sulfide liquid.

\subsection{Genetic model for the second type "intrusive" mineralization}

This type of mineralization is hosted by relatively evolved rock types, including norites, gabbronorites and gabbro containing irregular sulfide dissemination or nested sulfides, often varied-textured and always intruding more primitive and barren rocks of the complex. The mineralized zones occur as magmatic breccias with mineralized rocks in the matrix (Bottom ore layer, Gabbro-10, Fig. 1) or a series of mineralized veins of gabbronorite cutting orthopyroxenite (South Sopcha, Fig. 1).

There is no clear understanding of the origin of this mineralization in the Monchegorsk complex at the moment. However, noteworthy is the similarity of the geological structure of these mineralized zones to the Fedorova Tundra deposit, for which the intrusion of sulfidebearing magma, enriched in PGE at depth in a staging chamber, is a classical model of formation (Groshev et al. 2019, and references therein). Perhaps, this model is more reliable for the Gabbro-10 and South Sopcha intrusions (Pripachkin et al. 2015; Groshev et al. 2018), while an alternative model can be proposed for the "Bottom ore layer" which implies the downward migration of PGE-enriched sulfide liquid (first contact mineralization type) together with evolved silicate liquid along the contacts inclined towards central portions of the intrusion (Fig. 2). Another model for the origin of the "Bottom ore layer" is associated with the concept of a so-called "leg" of the Monchepluton supposed to be a feeder channel or norite-gabbronorite dike that controls the distribution of both contact-style PGE mineralization and massive sulfide veins (Ivanchenko 2017).

\section{Future prospects}

We hope to continue the discussion about the origin of the diverse sulfide mineralization in the Monchegorsk complex, which has begun in recent years (e.g., Bekker et al. 2015; Yang et al. 2016; Karykowski et al. 2018). The most interesting are the following questions. (1) Which of the two types of contact mineralization is more economically significant? (2) Is there a genetic 
relationship between the "intrusive" contact-style mineralization and massive sulfide veins that were mined in the Monchepluton until the 1970s (Fig. 2)?

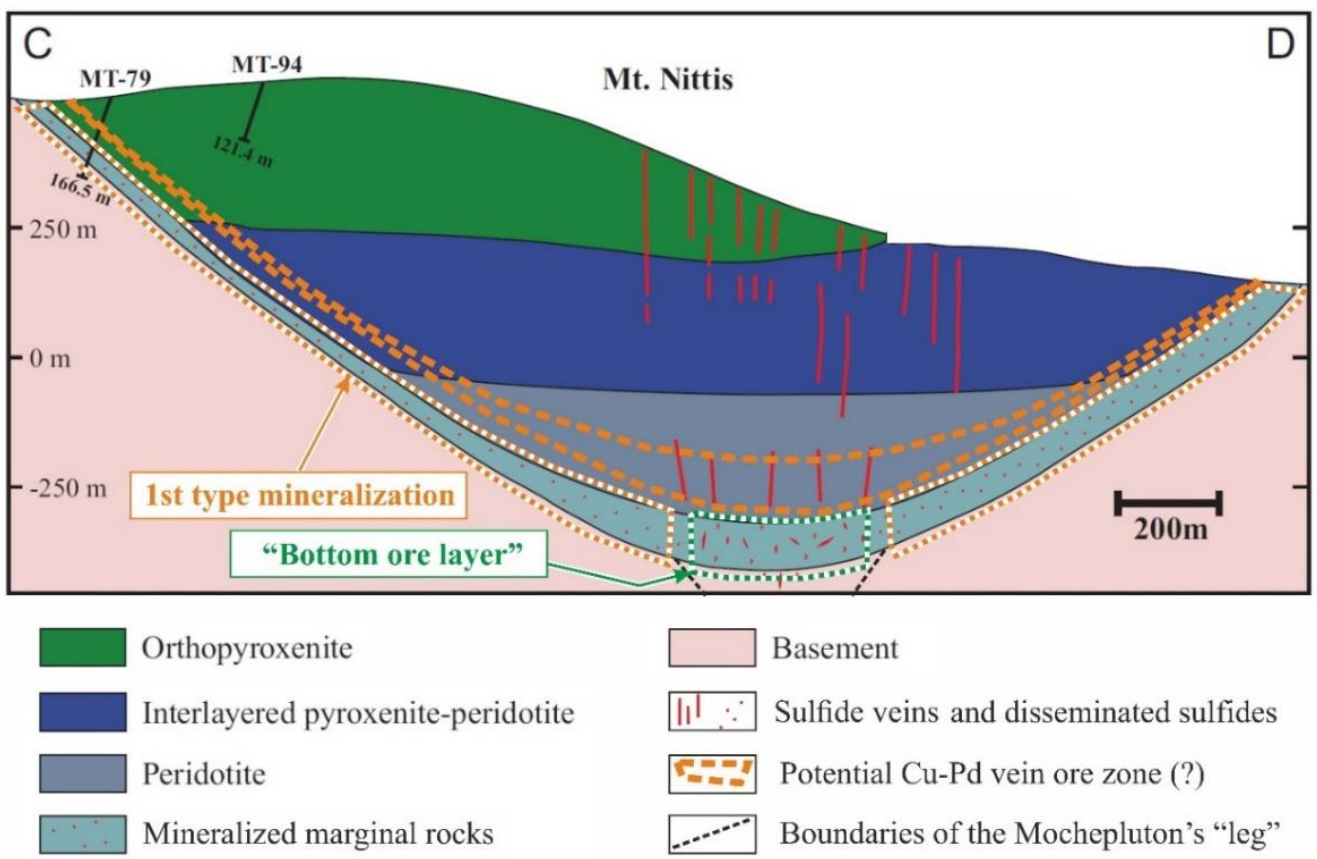

Figure 2. Schematic geologic cross section, profile C-D in Fig. 1.

\section{Acknowledgements}

Ministry of Science and Higher Education of the Russian Federation (project 0226-2019-0053).

\section{References:}

Bekker A, Grokhovskaya TL, Hiebert R, et al (2015) Multiple sulfur isotope and mineralogical constraints on the genesis of Ni-Cu-PGE magmatic sulfide mineralization of the Monchegorsk Igneous Complex, Kola Peninsula, Russia. Miner Depos. https://doi.org/10.1007/s00126-015-0604-1

Groshev NY, Pripachkin PV, Karykowski BT, et al (2018) Genesis of a Magnetite Layer in the Gabbro-10 Intrusion, Monchegorsk Complex, Kola Region: U-Pb SHRIMP-II Dating of Metadiorites. Geol Ore Depos 60:486496. https://doi.org/10.1134/s1075701518060028

Groshev NY, Rundkvist TV, Karykowski BT, et al (2019) Low-Sulfide Platinum-Palladium Deposits of the Paleoproterozoic Fedorova-Pana Layered Complex, Kola Region, Russia. Minerals 9:764 https://doi.org/10.3390/min9120764

Ivanchenko VN (2017) Prospecting for platinum group metals within the Monchegorsk ore district (Murmansk region). Report of joint-stock company "Rosgeo", Moscow

Karykowski BT, Maier WD, Groshev NY, et al (2018) Critical controls on the formation of contact-style PGE-Ni$\mathrm{Cu}$ mineralization: Evidence from the paleoproterozoic Monchegorsk Complex, Kola Region, Russia. Econ Geol 113:911-935. https://doi.org/10.5382/econgeo.2018.4576

Pripachkin PV, Rundkvist TV, Miroshnikova YA, et al (2016) Geological structure and ore mineralization of the South Sopchinsky and Gabbro-10 massifs and the Moroshkovoe Lake target, Monchegorsk area, Kola Peninsula, Russia. Miner Depos 973-992. https://doi.org/10.1007/s00126-015-0605-0

Rundkvist TV, Balashov YA, Skublov SG, et al (2016) Geochemistry and U-Pb age of zircons from the Vurechuaivench massif, Monchegorsk complex, Kola region. Geol Ore Depos 58:525-535. https://doi.org/10.1134/S1075701516070102

Sharkov EV, Chistyakov AV (2012) The Early Paleoproterozoic Monchegorsk layered mafite-ultramafite massif in the Kola Peninsula: Geology, petrology, and ore potential. Petrology 20:607-639. https://doi.org/10.1134/S0869591112070041

Sharkov EV (2006) Formation of Layered Intrusions and Related Mineralization. Nauchniy Mir, Moscow

Yang SH, Hanski E, Li C, et al (2016) Mantle source of the 2.44-2.50-Ga mantle plume-related magmatism in the Fennoscandian Shield: evidence from Os, Nd, and Sr isotope compositions of the Monchepluton and Kemi intrusions. Miner Depos 51:1055-1073. https://doi.org/10.1007/s00126-016-0673-9 